\title{
PERLINDUNGAN HUKUM TERHADAP PENERIMA HAK DALAM PERJANJIAN WARALABA DI INDONESIA
}

\author{
I Made Dwi Wahyu Kartika, Ni Made Jaya Senastri, Ni Gusti Ketut Sri Astiti \\ Fakultas Hukum, Universitas Warmadewa, Denpasar-Bali, Indonesia \\ wahyukartika284@gmail.com, nimadejayasenastri@gmail.com
}

\begin{abstract}
Abstrak
Waralaba merupakan sebuah konsep pemasaran dalam rangka memperluas usaha guna sebagai penunjang perekonomian, dalam hal ini seringkali terdapat permasalahan terkait perjanjian yang telah ditetapkan. Maka sebab itu dibutuhkan sebuah perlindungan hukum bagi penerima hak. Tujuan penelitian ini untuk mengungkap pilihan perjanjian dalam pelaksanaan perjanjian waralaba di Indonesia serta bentuk perlindungan hukum terhadap penerima waralaba di Indonesia. Metode penelitian dalam penelitian ini adalah normatif penelitian berfokus kepada perilaku masyarakat hukum dan melalui referensi buku ilmu hukum. Sumber data yang digunakan adalah data primer yaitu dengan meneliti peraturan yang berkaitan dengan waralaba dan data sekunder yaitu dengan meneliti literatur, buku, makalah dan jurnal. Teknik pengumpulan data dengan mengklasifikasikan bahan hukum primer dengan bahan hukum sekunder sebagai penunjang. Analisis Bahan Hukum diperoleh dengan analisis kualitatif. Hasil penelitian mengungkapkan bahwa bisnis franchise di Indonesia telah diatur dalam ketentuan PP Nomor 42 tahun 2007 tentang waralaba, untuk syarat sah berdirinya usaha waralaba harus memenuhi ketentuan dalam Pasal 1320 KUHPerdata, serta bentuk perlindungan hukum terhadap franchisee tertuang didalam Pasal 7 Peraturan Menteri Perdagangan Nomor 12/MDAG/Per/3/2006 jadi pihak franchisor tidak dapat memutuskan perjanjian setiap waktu atau kapan saja.
\end{abstract}

Kata Kunci: Perjanjian Baku, Perlindungan Hukum, Waralaba

\begin{abstract}
Franchising is a marketing concept in order to expand the business to support the economy, in this case there are often problems related to the agreement that has been set. Therefore, a legal protection is needed for the recipient of the right. The purpose of this study is to reveal the choice of agreement in the implementation of franchise agreements in Indonesia and the form of legal protection for franchisees in Indonesia. The research method in this study is normative research focusing on the behavior of the legal community and through legal science book references. Sources of data used are primary data by examining regulations related to franchises and secondary data by examining literature, books, papers and journals. Data collection techniques by classifying primary legal materials with secondary legal materials as a support. Analysis of Legal Materials obtained by qualitative analysis. The results of the study reveal that the franchise business in Indonesia has been regulated in the provisions of PP No. 42 of 2007 concerning franchising, for the legal requirements for the establishment of a franchise business, it must meet the provisions in Article 1320 of the Civil Code, and the form of legal protection for franchisees is contained in Article 7 of the Regulation of the Minister of Trade Number 12/MDAG/Per/3/2006 so the franchisor cannot terminate the agreement at any time or at any time.
\end{abstract} Keywords: Standard Agreement, Legal Protection, Franchise

\section{PENDAHULUAN}

Pada setiap transaksi-transaksi bisnis tentunya diperlukan suatu perjanjian sebagai dasar ataupun aturan main transaksi bisnis tersebut. Salah satu yang menonjol dalam bidang hukum perikatan, hal tersebut dikarenakan, banyak transaksi-transaksi bisnis yang di dalamnya berdasarkan pada perjanjian-perjanjian yang belum dikenal dalam Kitab Undang-undang Hukum Perdata (selanjutnya disebut KUH Perdata) atau disebut juga sebagai perjanjian innominaat, melainkan memakai konsepkonsep perjanjian yang ada di dalam sistem hukum common law. Salah satunya adalah perjanjian franchise (waralaba).

Bentuk franchise sepatutnya melingkupi beraneka macam aspek kehidupan, sedari pengetahuan hingga pada aspek restoran. Seperti yang diketahui bahwa bukuke-III KUH Perdata menganut asas kebebasan berkontrak, yang diatur dalam Pasal 1338 KUH Perdata dengan syarat tidak melanggar undang-undang, Ketertiban umum dan kesusilaan (Subekti, 2002). Waralaba merupakan 
salah satu bentuk kemitraan yang didasarkan pada hubungan yang saling menguntungkan antara pemberi waralaba (franchisor) dan penerima waralaba (franchisee). Dalam sistem waralaba, penerima waralaba diberi hak untuk memanfaatkan hak atas kekayaan intelektual dan sistem kegiatan operasional oleh penerima waralaba.

Bisnis waralaba mempunyai karakteristik tersendiri didalam kehidupan ekonomi yang dapat menimbulkan permasalahan dalam bidang hukum dikarenakan bisnis ini didasarkan pada suatu perjanjian yang menimbulkan hak dan kewajiban bagi para pihak, maka dalam hal ini diperlukannya perlindungan hukum bagi setiap pihak didalamnya (Sesaria et al., 2017).

Waralaba merupakan suatu perikatan yang tunduk pada ketentuan umum mengenai perikatan yang diatur dalam KUH perdata. Dasar hukum kontrak waralaba di Indonesia hingga kini belum diatur secara tegas meskipun demikian, terdapat beberapa pasal dalam KUH Perdata yang dapat dipengaruhi sebagai dasar dari adanya kontrak waralaba yaitu, Pasal 1320 KUHPerdata. Pasal ini menghendaki terjadinya suatu kontrak yang sah, maka perlu dipenuhi empat persyaratan diantaranya;

1. Kesempatan mereka yang mengikatkan diri;

2. Kecakapan untuk membuat suatu perikatan;

3. Suatu hal tertentu;

4. Suatu sebab yang halal.

Dalam persyaratan menurut ketentuan Pasal 1320 KUHPerdata di atas telah terpenuhi, kontrak yang dibuat itu berlaku sebagai undang-undang yang mengikat bagi mereka yang membuatnya (Syahmin, 2006). Perlindungan hukum dalam masyarakat adalah untuk mengintegrasikan dan mengkoordinasikan kepentingan-kepentingan yang biasa bertentangan antara satu sama lain. Oleh sebab itu, hukum layak guna untuk kredibilitasnya sampai-sampai kekacauan relevansi tersebut bisa dihilangkan semaksimal mungkin.

Perlindungan hukum ialah suatu langkah ataupun jalan guna membentengi khalayak oleh aksi sesuka hati bagi pemimpin yang dimana belum sebanding dengan peraturan hukum yang ada, guna menciptakan kesopanan dan keharonisasian sampai mengharuskan khalayak guna mengahayati derajatnya sebagai ciptaan tuhan yang sempurna Di Tengah lingkungan bisnis eksistensi permufakatan baku ialah menjadikan suatu fakta yang belum bisa dielakkan dimana ialah suatu yang berpengaruh guna terwujudnya daya guna kerja pelaku usaha. Perjanjian baku umumnya berisi klausa-klausa yang dibakukan pula, sesuai dengan karakter perjanjian baku terutama perjanjian baku yang sepihak pada umumnya lebih banyak melindungi kepentingannya sendiri dan cenderung merugikan pihak yang lainnya yang kurang dominan.

Jenis-jenis perjanjian baku/standar secara kuantitatif perjanjian baku yang hidup berkembang dalam masyarakat (dunia bisnis) sangat banyak, sebab pelaku usaha (perusahaan) selalu mempersiapkan standar baku dalam mengelola usaha. Dengan begitu bagian-bagian permufakatan baku bisa dilihat sejak penggolongan, Mariam Darus Badrulzaman yang mengkategorikan golongan permufakatan baku kedalam empat jenis :

1. Perjanjian baku/standar sepihak, yaitu perjanjian ini diisinya ditentukan oleh pihak yang kuat kedudukannya didalam perjanjian itu.

2. Perjanjian baku/standar timbal balik, yaitu perjanjian yang isinya ditentukan oleh kedua belah pihak.

3. Perjanjian baku/standar yang ditetapkan oleh pemerintah, yaitu perjanjian standar yang isinya ditetapkan oleh pemerintah terhadap pembuatan-pembuatan hukum tertentu.

4. Perjanjian baku/standar yang ditentukan di lingkungan notaris atau advokat.

Seraya dengan adanya kapabilitas ilmu teknologi dan pengetahuan yang istimewa serta biasanya lebih modern serta imajinatif, para wirausaha bisa memasarkan kemahiran tersebut pada khalayak lain guna memutar bisnisnya, Hal ini sering kali tidak menciptakan kemitraan usahaan, bahkan dalam perjanjian waralaba sering tidak melindungi kepentingan penerima waralaba sebagai akibat dari tidak dimilikinya kekuatan penerima waralaba timbulnya permasalah tersebut bisa disebabkan dari muatan permufakatan yang pada umumnya telah baku diserahkan oleh pihak franchisor terhadap pihak franchisee sudah sepatutnya pihak franchisee dapat melaksanakan tindakan menolak pada muatan permufakatan yang dimana bisa menyusahkan pihak franchisee sendiri seperti yang diatur dalam syarat sah nya perjanjian Pasal 1320 KUH Perdata yaitu dalam pembuatan perjanjian harus dibuat dan disepakati oleh kedua belah pihak. Contoh waralaba yang berkembang di indonesia yaitu seperti ayam geprek, kedai kopi, jco donuts, es krim. Berdasarkan pemaparan latar 
belakang masalah diatas, maka penulis tertarik untuk menganalisa penerimaan hak dalam perjanjian waralaba di Indonesia.

Jika ditinjau dari sudut pandang hukum franchise merupakan perjanjian legal antara dua pihak dalam bekerjasama memproduksi, merakit, menjual, memasarkan suatu produk jasa (Hanim, 2011). Perjanjian franchise sangat diperlukan sebagai salah satu syarat administratif bagi franchisee untuk mendapatkan Surat Tanda Pendaftaran Waralaba (STPW) sebagai bukti sebuah perusahaan penerima waralaba (franchisee) sesuai yang tertera dalam pasal 5 Perturan Pemerintah No.42 tahun 2007 tentang waralaba kedua belah pihak harus memenuhi kriteria dalam membuat perjanjian (Putri, 2020). Adapun penelitian yang dilakukan oleh Cahyadi et al., (2020) mengungkapkan bahwa bentuk perjanjian franchise belum dapat memberikan perlindungan hukum bagi franchisee, usaha waralaba yang diberikan oleh PT. Sumber Alfaria Trijaya Tbk kepada CV. Putra Mas dikarenakan praktek bisnis franchise yang berlangsung belum berpijak pada asas kebebasan berkontrak sebagaimana dalam pasal 1338 juncto Pasal 1233 KUHPerdata.

Maka berdasarkan uraian diatas, tujuan dari penelitian ini adalah untuk mengungkap pilihan perjanjian dalam pelaksanaan perjanjian waralaba di Indonesia serta bentuk perlindungan hukum terhadap penerima waralaba di Indonesia.

\section{METODE PENELITIAN}

Tipe penelitian dalam penelitian ini adalah penelitian hukum normatif, Sumber bahan hukum yang diterapkan dalam observasi berikut terdapat 2 bahan hukum yaitu bahan hukum primer meliputi peraturan Perundang-undangan yang berlaku di Indonesia serta bahan hukum sekunder meliputi bahan hukum tertulis berupa literatur jurnal yang ditulis oleh para ahli, Teknik pengumpulan bahan hukum dalam penulisan ini diklasifikasikan berdasarkan bahan hukum primer, dengan bahan hukum sekunder sebagai penunjang, Dalam penelitian ini adapun pengolahan dan analisis bahan hukum yang dilakukan yaitu dengan menggunakan analisis kualitatif.

\section{HASIL DAN PEMBAHASAN}

\section{Pilihan Perjanjian dalam Pelaksanaan Perjanjian Waralaba di Indonesia}

Ketetapan-ketetapan yang memikul adanya suatu kejelasan hukum pada struktur usaha franchise ialah

1. Undang-Undang No. 5 Tahun 1999 Tentang Larangan Praktek Monopoli dan Persaingan Usaha Tidak Sehat. Di dalam Undang- Undang ini terdapat ketentuan mengenai pengecualian. pengkhususan yang tercatat pada ketetapan-ketetapan berikut tentunya belum membagikan definisi yang spesifik perihal dikecualikannya perjanjian frenchise.

2. Peraturan Pemerintah Nomor 42 Tahun 2007 Tentang Waralaba.

Pihak frenchisor diharuskan menerangkan selebaran usaha waralabanya terhadap pihak franchisee, keabsahan bisnis pihak franchisor, riwayat aktivitas bisnisnya, susunan formasi franchisor, informasi finansial dua tahun belakang, banyaknya lokasi bisnis, susunan franchise, maupun kewenangan serta tanggung jawab dari pihak franchisor dan pihak franchisee (Asyadie, 2012).

3. Perjanjian Sebagai Dasar Hukum

(H.S, 2011) Pasal 1338 ayat (1) KUH Perdata menegaskan mengenai berlakunya asas kebebasan berkontrak yaitu bahwa para pihak bebas melakukan kontrak apapun sepanjang tidak bertentangan dengan hukum positif, kepatutan dan ketertiban umum. Sehubungan dengan bentuk perjanjian waralaba, Pasal 4 ayat (1) PP tentang waralaba, menentukan bahwa waralaba diselenggarakan berdasarkan perjanjian tertulis antara pemberi waralaba dengan penerima waralaba dengan memperhatikan hukum Indonesia. Berdasarkan ketentuan pasal 4 ayat (1) pp tentang waralaba ini jelas dimengerti bahwa apabila pemberi dan penerima waralaba telah sepihak maka perjanjian waralaba harus dibuat dalam bentuk perjanjian tertulis, Salim H.S menyebutkan ada tiga bentuk perjanjian tertulis yaitu :

a. Perjanjian di bawah tangan di tanda tangani oleh pihak yang bersangkutan saja.

b. Perjanjian dengan saksi notaris untuk melegalisir tanda tangan para pihak.

c. Perjanjian yang dibuat dihadapan dan oleh notaris dalam bentuk akta notaris

Ketentuan-ketentuan peraturan perundang-undangan memastikan bahwasannya perjanjian yang absah ialah perjanjian yang berkapasitas menjadi ketetapan-ketetapan. seluruh kesepakatan yang 
dilakukan sebagai yang absah berlangsung menjadi ketetapan-ketetapan oleh para pihak yang mengerjakannya. Persetujuan-persetujuan itu tidak dapat ditarik kembali, selain kesempatan kedua belah pihak atau karena alasan-alasan yang oleh undang-undang dinyatakan cukup untuk itu.

Menurut Sutedi (2011) pada tiap jenis kesepakatan usaha franchise memiliki beberapa elemen-elemen adalah sebagai berikut :

1. Adanya minimal dua pihak, yaitu pihak franchisor dan pihak franchise.

2. Adanya penawaran dalam bentuk paket usaha dari franchisor

3. Adanya kerjasama dalam bentuk pengelolaan unit usaha antara pihak franchisor dengan franchise.

4. Dipunyai Nya unit usaha tertentu (outlet) oleh pihak franchise yang akan memanfaatkan paket usaha milik pihak franchisor.

5. Terdapat kontrak tertulis berupa perjanjian baku antara pihak franchisor dengan pihak franchise.

Kesepakatan bisnis franchise ini tentunya mesti dibuatkan secara tertulis dalam bahasa Indonesia, perihal tersebut beralaskan dengan ketentuan dalam Pasal 4 ayat (1) Peraturan Pemerintah Republik Indonesia Nomor 42 Tahun 2007 Tentang Waralaba. kesepakatan franchise atas latar belakangnya tidak harus dikerjakan pada format akta notaris, akan tetapi pihak franchise dan pihak franchisor bisa melakukannya sendiri membuat suatu akta dibawah tangan beralaskan ketetapanketetapan yang telah diatur dalam KUHPerdata. Ketentuan absahnya suatu kesepakatan usaha franchise sama dengan dalam kesepakatan-kesepakatan lainnya, dimana harus patuh pada ketentuan yang diatur pada Pasal 1320 KUHPerdata, yaitu antara lain:

1. Kesepakatan

Definisi sepakat dilukiskan menjadi suatu perjanjian kemauan maupun kepentingan yang telah dimufakatkan oleh para pihak.

2. Kecakapan

Yang dimaksud kecakapan disini yaitu para pihak yang membuat perjanjian harus mampu untuk melakukan suatu perbuatan hukum.

3. Suatu Hal Tertentu

Arti suatu hal tertentu disini adalah bahwa perjanjian dicantumkan apa yang menjadi objek dari perjanjian tersebut.

4. Suatu Sebab Yang Halal

Suatu sebab yang diperbolehkan disini memiliki pengertian bahwa perjanjian tersebut tidak bertentangan dengan undang- undang, agama,ketertiban umum dan kesusilaan.

Substansi dari kesepakatan franchise dimohonkan bisa mengamankan pada para pihak, baik pihak pemberi waralaba maupun pihak penerima waralaba. Oleh sebab itu, perlu bagi pihak pemberi waralaba sebelum melaksanakan ulasan pada substansi kesepakatan bisnis waralaba sebelum melaksanakan penandatanganan. Bilamana pada kesepakatan-kesepakatan genting yang nantinya sensitif memicu persoalan, salah satunya contohnya seperti klausula kerahasian. Harus diberikan interferensi dan batas yang tepat untuk klausul tersebut.

Perjanjian baku atau (standar contract) memiliki karakteristik sebagai ciri-ciri dari suatu perjanjian baku sebagai berikut :

1. Isinya ditetapkan secara sepihak oleh pihak yang posisi (ekonominya) kuat.

2. Masyarakat (debitur/konsumen) sama sekali tidak bersama-sama menentukan perjanjian.

3. Terdorong oleh kebutuhannya debitur/konsumen terpaksa menerima perjanjian itu.

4. Bentuk tertentu (tertulis).

5. Dipersiapkan secara massal dan kolektif.

\section{Bentuk Perlindungan Hukum Terhadap Penerima Waralaba di Indonesia}

Perjanjian berdasarkan dalam rumusan Pasal 1313 KUHPerdata merupakan satu kegiatan yang mana terdiri dari 1 individu ataupun lebih yang mana mengikatkan pada dirinya sendiri kepada 1 individu lain ataupun lebih. Oleh sebab itu bahwasannya dalam satu kesepakatan timbulah suatu tanggungjawab ataupun prestasi oleh 1 individu ataupun lebih individu (pihak) terhadap 1 ataupun lebih individu (pihak) lainnya yang dimana berwenang terhadap prestasi atau janjinya tersebut.

Van Dunne menyebutkan bahwa perjanjian atau kontrak adalah suatu hubungan hukum antara dua pihak atau lebih berdasarkan kata sepakat untuk menimbulkan akibat hukum. Definisi ini 
telah memuat perbuatan hukum meliputi pra kontraktual, tahap kontraktual dan post kontraktual (H.S, 2007). Kehadiran usaha franchise di Indonesia sudah bisa diakui dikarenakan pada usaha franchise tersebut mempunyai dua faktor yaitu faktor perjanjian serta faktor lisensi, jadi bahwasannya semua kualifikasi serta substansi dari perjanjian tersebut sudah ditentukan semuanya oleh pihak franchisor. Terdapat sejumlah klausul-klausul pada kesepakatan usaha franchise ini adalah sebagai berikut:

1. Sifat perjanjian dari waralaba sangat pribadi yang maksudnya adalah bahwa hak dan kewajiban penerima waralaba tidak mudah dialihkan kepada pihak lain, baik dengan cara jual beli, maupun karena pemindahan hak dan kewajiban penerima waralaba.

2. Posisi pemberi waralaba lebih kuat karena dapat memutuskan perjanjian secara sepihak atas dasar adanya pelanggaran atau kesalahan dari penerima waralaba dalam menjalankan usahanya.

3. Pada saat berakhirnya perjanjian atau bila perjanjian waralaba itu tidak diperpanjang lagi, penerima waralaba diwajibkan mengembalikan dan menghentikan seluruh penggunaan merek pemberi waralaba, nama dagang/jasa, trade secret, know-how, termasuk pula pemulangan semua barang atau benda yang dimana bersangkut paut terhadap ciri-ciri pihak franchisor contohnya ialah daftar menu, point of sale serta desain outlet yang dipunyai oleh pihak franchisor.

4. Bila ada perubahan atau penambahan pada outlet milik penerima waralaba yang dimintakan oleh pemberi waralaba, yang mana menurut pemberi waralaba penambahan atau perubahan tersebut sangat dibutuhkan dalam rangka perbaikan kualitas suatu toko/outlet/gerai, oleh karenanya semua dana yang diakibatkannya adalah menjadi kewajiban dari pihak franchisee.

5. Jika toko/outlet/tempat usaha perlu direnovasi ataupun dipindahkan berdasarkan atas keinginan pemberi waralaba setelah diadakan perpanjangan perjanjian, maka kewajiban penerima waralaba adalah harus mengikuti kehendak pemberi waralabaMenjadikannya satu peraturan sosial pada aktivitas ekonomi, hadirnya usaha franchise ini sudah melahirkan suatu persoalan pada ranah hukum. Hal ini sebagai akibat adanya hubungan-hubungan dalam sistem waralaba (franchise) yang dibangun atas dasar hubungan kontrak, yang dikenal dengan kontrak franchise. Kontrak franchise adalah suatu kaidah hukum yang mana menggariskan suatu kewajiban pada pihak franchisor serta pihak franchisee.

Perjanjian waralaba sangat erat hubungannya dengan pemberian lisensi untuk memanfaatkan hak kekayaan intelektual tertentu sebagai salah satu kriteria waralaba yaitu HKI (Hak Kekayaan Intelektual) yang telah terdaftar mengacu pada Pasal 3 Peraturan Pemerintah Republik Indonesia Nomor 42 Tahun 2007. Yang dimaksud dengan HKI (Hak Kekayaan Intelektual) yang telah terdaftar adalah Hak Kekayaan Intelektual yang terkait dengan pelaksanaan usaha waralaba seperti Hak Cipta, Hak Paten, Hak Merek dan Rahasia Dagang yang sudah didaftarkan dan mempunyai sertifikat. Dalam hal ini waralaba bisa termasuk kedalam 3 hak yaitu :

1. Hak Cipta : memungkinkan perlindungan hukum terhadap waralaba dari kemampuan, imajinasi, kecekatan, atau keterampilan yang dituangkan dalam bentuk khas dan pribadi,

2. Hak Paten : memberikan Perlindungan Hukum Hak Paten terhadap waralaba terhadap kemungkinan adanya usaha peniruan,

3. Hak Merek : memungkinkan perlindungan hukum terhadap waralaba berkaitan dengan nama perusahaan, Logo, dan lambang suatu perusahaan.

\section{SIMPULAN DAN SARAN}

\section{Simpulan}

Setelah diberlakukannya Peraturan Pemerintah Nomor 42 Tahun 2007 tentang Waralaba di Indonesia diatur sesuai dengan Peraturan Pemerintah Nomor 42 Tahun 2007 tentang Waralaba yang merupakan peraturan pemerintah pengganti Peraturan Pemerintah Nomor 16 Tahun 1997, maka pilihan hukum dalam perjanjian waralaba adalah perjanjian baku yang tertuang didalam pasal 3 PP Nomor 42 Tahun 2007. Selain itu, secara umum pengaturan mengenai Waralaba juga terdapat pada Kitab Undang-Undang Hukum Perdata pada Pasal 1338 tentang syarat sah perjanjian, Pasal 1341 tentang perlindungan terhadap hak-hak yang dimiliki oleh pihak yang dirugikan tersebut di dalam perjanjian, dan Peraturan Menteri Perdagangan Republik Indonesia Nomor 53/MDAG/PER/8/2012 tentang Penyelenggaraan Waralaba. Adapun bentuk perlindungan hukum terhadap franchisee dalam 
perjanjian dengan franchisor terdapat dalam Peraturan Menteri Perdagangan Nomor 12/MDAG/Per/3/2006 yang terdapat dalam Pasal 7 bahwasannya jangka waktu perjanjian waralaba (franchising) antara Pemberi Waralaba dengan Penerima Waralaba Utama berlaku paling sedikit 10 tahun dan Jangka Waktu Perjanjian Waralaba antara Penerima Waralaba Utama dengan Penerima Waralaba Lanjutan berlaku paling sedikit 5 tahun. Dalam peraturan berikut ini menjadikannya mendapat suatu payung hukum yang jelas kepada pihak penerima waralaba, karena oleh dari pada itu pemberi waralaba tidak bisa membatalkan suatu perjanjian pada waktu kapan saja. Ketentuan hukum yang melindungi pihak franchisee apabila mendirikan usaha yang serupa setelah perjanjian waralaba berakhir dapat dilihar dari Pasal 1338 KUH Perdata menggambarkan adanya asas kebebasan berkontrak akan tetapi kebebasan ini dibatasi oleh hukum yang bersifat memaksa sehingga franchisor sebagai pihak dominan dilarang untuk membuat perjanjian yang sewenang-wenang.

\section{DAFTAR PUSTAKA}

Asyadie, Z. (2012). Hukum Prinsip dan Pelaksanaan di Indonesia. Rajawali Pers, Jakarta.

Cahyadi, A., Aminah, \& Sukma, N. M. (2020). Perlindungan Hukum Merek Jasa di Dalam Perjanjian Waralaba Alfamart. NOTARIUS: Jurnal Studi Kenotariatan, 13(1), 1-11.

H.S, S. (2007). Perancangan Kontrak dan Memorandum of Understanding (MoU). PT Sinar Grafika, Jakarta.

H.S, S. (2011). Hukum Kontrak Teori dan Teknik Penyusunan Kontrak. Sinar Grafika, Jakarta.

Hanim, L. (2011). Perlindungan Hukum HaKI Dalam Perjanjian Waralaba di Indonesia. Jurnal Hukum Unissula, 26(2), 571-589.

Putri, E. A. (2020). Perlindungan Hukum Bagi Para Pihak Dalam Perjanjian Usaha Waralaba (Franchise). Tadulako Master Law Journal, 4(2), 174-200.

Sesaria, A., Prananigtyas, M., \& Mahmudah, S. (2017). Perlindungan Hukum Bagi Penerima Waralaba di Kabupaten Kendal (Studi Pada Alfamart Desa Pucang Rejo). Diponegoro Law Journal, 6(1), 1-12.

Subekti. (2002). Hukum Perjanjian. Intermasa, Jakarta.

Sutedi, A. (2011). Hukum Perizinan dalam Sektor Pelayan Publik. Sinar Grafika, Jakarta.

Syahmin. (2006). Hukum Perjanjian Internasional. PT. Raja Grafindo Persada, Jakarta. 